\title{
ENGLISH CURRICULUM DEVELOPMENT OF ELEMENTARY SCHOOL AT SDNU BANAT BANIN LAMONGAN
}

\author{
Agus Sholeh, Mukhtarul Anam \\ sholehagus11@gmail.com, mukhtarul4nam@gmail.com \\ Program Studi Pendidikan Bahasa Inggris, Universitas Islam Lamongan
}

\begin{abstract}
In this modern era, learning English is a must for every human. therefore, learning English at early level is better done. This time, it is determined that English subjects in elementary schools are local content group subjects whose status is as elective subjects, so the material is determined by each school. This research was using Qualitative descriptive. It is about An Analysis English Curriculum Development at SDNU Banat Banin lamongan. The Subject of the research was the teacher and the 5-grade at SDNU Banat Banin Lamongan in the academic year of 2019/2020. There are 30 students. The finding of the research, the curriculum applied at SDNU Banat Banin Lamongan was the 2013 curriculum and the researcher found four aspects that are done by SDNU Banat Banin Lamongan as curriculum development in learning English starting from the purpose of curriculum development, learning material, learning methods, and learning evaluation and the material presented in fifth grade in SDNU Banat Banin Lamongan is grammar, translating text, making sentences, and knowing the difference in the meaning of a word and once every week on Wednesday there is a habit of Speaking English .
\end{abstract}

Keywords: English learning, curriculum development

\section{INTRODUCTION}

In this modern era, learning English is a must for every human, therefore learning English at early level is better done. In this case it is different from the previous policy which provides opportunities starting from the first semester of first grade at junior high school. This time, it is determined that English subjects in elementary schools are local content group subjects whose status is as elective subjects, so the material is determined by each school. Meanwhile, in the next level English as a compulsory subject to date. Because of their status as elective subjects, so at different levels of implementation. Some schools start teaching it in fourth grade, some others start teaching it from the first grade of elementary school and some even haven't taught it until 2020. In this case, the government decided a policy of allowing elementary schools (SD) to teach English starting from the fourth grade (Depdikbud : 1994).

English learning in Indonesia is still facing various problems. This is evident from several research results and reports that show that the mastery of English in Indonesian students, in general, are still low. According to Sukamerta (2013: 4) says that the mastery of English graduates of basic education in Indonesia is not successful compared to other countries, such as Malaysia and Singapore. The failure to master English is influenced by non-linguistic factors, such as the environment, culture, economy, family background, educational facilities, student attitudes, and parents. All of these factors greatly affect student achievement in English as a foreign language.

English is an international language. Therefore, when we want to communicate with foreigners, we can use English as an international language, so that, in education of Indonesia, language skills are one of the skills that must be mastered by students earlier. In this case, learning English is directed at four skills are listening ability, speaking, reading, and writing ability. 
One way to achieve learning is through the interaction of the teaching and learning process. Teaching and learning interactions contain meaning that the teaching and learning activities of teachers and students in this interaction will influence each other, meaning students do not learn from their teachers but teachers will also learn a lot from these activities carrying out teaching assignments at certain institutions. Teaching and learning interactions can occur within institutions, whether in the form of schools, households, or social institutions. That known as formal, and informal. Schools are institutions that are formally responsible for the sustainability of the education process. Education that informal education institutions are education directed at specific goals. To be able to realize these goals, the curriculum is a tool that brings all educational activities to the desired goals.

The curriculum is a "guideline" in determining the goals and direction of education in the future. With the curriculum, the education process will run in a clear direction. In the curriculum process, education will be a reference that must be used as a guide, both by managers and by education providers. The curriculum is occupying a very important position in education, because it is related to components, content, goals, methods, processes, to education evaluation which in turn will determine the types and qualifications of graduates.

In the National Education System No. 20 of 2003 Article 1 paragraph 19, that is the curriculum is a set of plans and arrangements regarding the content, objectives, and learning materials as well as the ways used as guidelines to regulate learning activities to achieve certain goals. Therefore, in its development, it must be able to adapt to the changing times and the development of science and technology. Historically-chronologically, the education curriculum in Indonesia itself has undergone various revisions, adjusted to the mainstream that developed at that time. Many things that the development of the direction of thinking to renew the education curriculum, one of which is the centralization of education so that later the space for a democratization of education gets a decent portion. In this case, the Minister of National Education has a dominant role in determining all the desires of the authorities, in this context the politicization of the education world is very influential in the phenomenon of life.

In the history of the curriculum in Indonesia, since 1947 until now it has experienced repeated curriculum changes, from the 1947 curriculum, the 1952 curriculum (Disciplinary Learning Plan), the 1964 curriculum (1964 Education Plan), the 1968 curriculum, the 1975 curriculum, the 1975 curriculum, the 1984 curriculum, the curriculum 1994, 2004 curriculum (KBK), KTSP curriculum, the latest with the emergence of the 2013 curriculum. Curriculum changes are intended to adjust the curriculum itself so that it can adjust with time. When examined, the essence of changes in the 2013 curriculum touches on four aspects, namely passing, process standards, content standards, assessment standards.

In the education system, SD does not have a national curriculum but as a school that has superior quality, SDNU Banat Banin Lamongan is one of the educational institutions that develop its education system. This school is a school that is famous for all the developments in science and technology (IPTEK) and IMTAQ and creates graduates who can compete with other schools. SDNU Banat Banin Lamongan is a school that is very concern with intellectual intelligence and spiritual intelligence.

\section{English Learning}


English becomes the major international language of printed information. A great deal of the world's scientific, commercial, economic, and technological knowledge are written and published in English. The new era and globalization today demand many people to master English as an international language. By mastering English well, they could absorb and expand knowledge, technology, and culture. They also could communicate with other people from other countries. The Indonesian government has chosen English as the first foreign language which is taught in Indonesia's schools. There are three functions of the teaching of foreign language in Indonesia. The functions are as follow:

1. As a means of international communication

2. As an aid to develop the Indonesian language into a modern one

3. As an instrument in utilizing modern science and technology for development

According to Wolfgang Klein, (Melbourne: Cambridge University Press, 1990), The meaning of foreign language is different from the second language. The difference is on the usage. If the language mentioned has a communicative function in a certain society or used in daily activities, for instance, Bahasa Indonesia, in the Javanese society, the language is called a second language. But if the language has no certain function in daily communication in society, for instance, English and Mandarin in Indonesia, the language is considered as a foreign language. Language learning means acquiring the ability to ask and answer questions, to make statements, and to produce the normal authentic, forms used by native English speakers.

The main characteristics of foreign language learning are in amount and type of exposure to the language. The children will have very little experience of the language outside the classroom, and encounters with the language will be through several hours of learning in a school. In foreign language teaching, there is an onus on the teacher to provide exposure to the language and to provide opportunities for learning through classroom activities. There are three backgrounds to learning English as follow: 1. Learning English as a First Language.

2. Learning English as a Second Language.

3. Learning English as a Foreign Language.

There are two kinds of language learners, they are as follow:

1. Young learners

According to Kasihani K. E. Suyanto,(Jakarta: Bumi Aksara, 2007), The definition of young learners is the students for elementary school which attain the age about 6 to 12 . 19 They were divided into two groups, younger group (6-8-year-old) and older group (9-12-year-old). According to the class, they called lower classes, first, second, and third, and upper class, fourth, fifth, sixth class. Meanwhile, Scott divides them into level one or first step (5-7year-old) and levels two (8-10-yearold). Level two groups, usually called a beginner when they start to study English at those levels.

Sarah Phillips stated that "young learners, means children from the first year of formal schooling (five or six years old) to eleven or twelve years of age".

Kenneth T. Henson and Delmar Janke (1984) said that the most important characteristics of young learners are their tendency to be active, some of the more active than others. Teachers should be concerned about children whose behavior is extremely passive or active. Another characteristic of children that is almost noticeable as their high level of activity, they tend to be curious. You have undoubtedly 
noticed how alert children are to the many things in their environment and how quickly their attention shifts from one aspect to another.

2. Adult learners

Younger children tend to be influenced by their feelings for their teacher. The main differences between the older and younger are that older people can consider the importance of studying English but often become less interested, embarrassed by having to learn a language or even hostile because they do not want to seem foolish in front of their friends. Different from children, the seven to eight-year people may be too young to feel any need for English; their attitude is mainly affected by whether they like the friends feel about English. Children tend to be more enthusiastic than older. The social environment also influences the children's interest in learning English.

According to Douglas Brown, (San Fransisco State University: Longman, 2001), The other characteristics between children and adults as language learners are; first, children have shorter attention than adults. It means children can't keep concentration and interest in learning material and activity for a long time. They will be bored with monotonous learning. But, adults are more able to keep concentration and interest in learning material and activity. Second, learning for children should be fun and natural. By this, they will be fun and will not be afraid to study. It is easier for children to understand the lesson through non-formal teaching, playing, and singing. But for an adult can be easy to understand the lesson through formal teaching. They can analyse their new knowledge with their old knowledge. Thus, they acquire the
English language consciously. Third, the children acquire grammatical rules inductively and the adult acquires grammatical rules deductively. When learning grammatical rules, the children can understand it through example. If they are given the patterns of the grammatical rule first, they will be difficult to understand. Different from children, the adult can understand the pattern of grammatical rules before seeing some examples. They can develop their abstract thinking ability.

\section{Curriculum Development}

The development of education in Indonesia is indicated by the development of the curriculum. As stated previously that curriculum change is a logical consequence of the change in the political system, social, cultural, economic, and science. The national educational curriculum has experienced changes in the year 1947, 1952, 1968, 1975, 1984, 1994, 2004, 2006, and the latest is 2013. The entire national curriculum is designed on the same basis, the Pancasila and 1945 Constitution; the different emphasis on basic education goals and implementation approach.

1. Curriculum 1968 and Before.

The first curriculum in Indonesia after independent day is the curriculum 1947 (a Subject Plan 1947/ Rencana Pelajaran 1947). As quoted by Hien, the curriculum was outlined into three columns: class, Contact-hour per week, and teaching materials. The curriculum was organized to replace the Netherlands' educational system and developed to establish the Indonesian people's character.

In 1952, there was an improvement of the curriculum in Indonesia which is known as unravelling Subject Plans 1952 (Rencana Pembelajaran Terurai 1952). 
The 1953 curriculum leads to the curriculum of the national education system in which every lesson plan must consider the content of the subjects connected to everyday life. According to O. Komaria, it was outlined in five columns: Class, Number of Contact Hours per week, Topic, Lesson, and remark.

According to H.A.R.Tilaar and Oemar Hamalik (1964), the Indonesia government improved the national educational system. The name was the Education Plan 1964, and the learning program focused on Pancawardhana. Concerning Pancawardhana, Tilaar stated that it is an educational policy which contains principles of the development of patriotism based on national, international, and religious orientation. It is implemented for the development of intelligence, emotion handcraft, and physical.

2. Curriculum 1975, 1984, and 1994.

The Ministry of Education and Culture established the curriculum 1975 to substitute the curriculum1968 under the Ministerial Decree No.008d/U/1975 and 008e/U1975 dated on January 15, 1975. This curriculum generally aimed at enhancing the quality of the Indonesian national education, and specifically this curriculum was objective-oriented in the sense that the teacher needed to know the students' objective in learning a certain item of knowledge, science, or skill (goal/ objective oriented). The integrated approach was adopted, and structuralism philosophy was a foundation of the curriculum. It was influenced by behaviour psychology that emphasizes the stimulus to response and training (drill).
In 1984, the curriculum 1984 was established to rectify the curriculum 1975. The previous curriculum was considered no longer compatible with the needs of the community and the demands of science and technology. The structural approach applied in the curriculum in 1975 had not been successful yet, especially. viewed from the students' need to have communicative competence. The curriculum 1984 oriented to instructional goals, and learning in the classroom must be functional and effective. The teaching approach was student-cantered through students' active learning system (Cara Belajar Siswa Aktif- CBSA) to improve students' communicative competence.

By the year 1994, the curriculum 1984 was considered that it needed to be revised. The learning process in the previous curriculum emphasizes the theory of learning and less attention to the content of the lesson. According to O. Komaria, the curriculum 1994 was established as the completion of the curriculum 1984 with Education Law No.2 in 1989 about the National Educational System. This curriculum applied a meaningful-based approach, communicative approach, and the system of learning time was changed from the semester to the quarter system. However, during the implementation of the curriculum, there were some problems because too many approaches should be oriented, the number of subjects, and too much substance of each of the subjects.

3. Competence-Based Curriculum (CBC, the Curriculum 2004). 
As a response to the structural change in the government from centralistic to decentralist, the curriculum 1994 needed to be refined. It was a logical consequence of the implementation of Act No. 22 and 25 in 1999 about Regional Autonomy. The curriculum developed at the time was called Competence-Based Curriculum which focused on developing the ability to do (competence) duties by certain performance standards that had been set. Based on Decree of the Minister of Education No. 045/U/2002 about Core Curriculum, Competence is a set of intelligent actions, so a competent person has full responsibility as a condition to be considered capable by the society in carrying out tasks in a particular field of work.

4. School-Based Curriculum (KTSP, The Curriculum 2006).

KTSP (Education Unit Level Curriculum) or School-Based Curriculum is the curriculum developed by the operational and implemented in each educational unit (school). This curriculum is implemented based on some regulations, namely:

a. The Act (UU) No.20 in 2003 about the National Education System.

b. The Act (UU) No. 32 in 2004 about Regional Autonomy, included in Education.

c. The Government Regulation (PP) No. 19 in 2005 about National Education Standard.

d. Ministerial Decree (MD) No. 22 in 2006 about Content Standard (SI)

e. Ministerial Decree (MD) No 23 in 2006 about Graduate Competency Standard (SKL) f) Ministerial Decree (MD) No. 24 in 2006 about The Implementation of SI and SKL.

The essential difference between the Competence-Based Curriculum
(CBC) and School-Based Curriculum (SBC/KTSP) did not exist. Both had a set plan of competencies oriented and learning outcomes of students. The difference is just on technical implementation. If the $\mathrm{CBC}$ is prepared by the central government, in this case, the Ministry of Education (Puskur CQ), then KTSP is prepared by the educational level of each unit; in this case, the school is concerned, though still referring to the national guidelines. The Guidelines for Developing Curriculum is prepared by the independent agency so-called the National Education Standards Agency (BSNP).

5. The 2013 Curriculum

he newest curriculum applied in Indonesia education is the curriculum 2013. The implementation of the curriculum in 2013 is started in July 2013; however, it is still for certain schools and levels of education. The goal of the curriculum 2013 is to produce Indonesian people who are productive, creative, innovative, and effective through the empowerment of integrated attitude, skill, and knowledge.

Nur Ahid (2013) said that the difference between the curriculum 2006 and curriculum 2013 is in the learning plan. In the curriculum of 2006, the syllabus development is under the education unit's (school) authority; however, in the curriculum 2013, the development is the central government's authority, except for special subject which is developed by a certain school. Even though the syllabus is from the central government, the teachers still have the authority to design a lesson plan and develop the materials given for operationalizing in learning.

\section{METHOD}


Based on the title in the study, that is "English Curriculum Development of Elementary School at SDNU Banat Banin Lamongan" then in this study, researcher use descriptive qualitative methods. Qualitative research, in general, can be used for research on community life, history, behaviour, functional, organization, social activities, and others. Descriptive method that is designed to gather information about current real conditions that aim to describe the current state of research (Sugiyono, 2016: 8) Descriptive qualitative research is obtained from observations and interviews and documentation. This study describes the activities of students, the activities of teachers in Teaching English of fifth grade at SDNU Banat Banin Lamongan.

The subjects of data collection in this study were English language teachers, principals, and learning processes in the fifth grade at SDNU Banat Banin Lamongan with a total of 30 students. And The object of research in this study is the implementation of English learning in the 2013 curriculum and the development carried out at SD NU Banat Banin Lamongan and observing learning tools such as Document Curriculum,syllabus, lesson plans (RPP), and Guidebook that used in the learning process.

The researcher conducts the data in the field. The research starts on March 2020. This research takes place at SD NU Banat Banin Lamongan located on Jl. Kiyai Amin Lamongan.

The Source of data used in this study is qualitative data. The data sources are:

\section{Primary Data}

Primary data is the data taken from primary data sources. Primary data sources are the results of interviews with principal and interview with English teachers related to the research title.

\section{Secondary Data}

Secondary data is data obtained from secondary sources. Secondary data referred to in this study are school documents, guidebooks, lesson plans, syllabus.

In this study, there are some steps that the researcher does to get the data from subjects in the field. The researcher conducts the observation, interview, documentation to get the data. The steps are as follows:

a. Observation

Data collection activities in the form of observations are conducted to observe how the implementation of learning English in SDNU. The type of activity used is participant observation in which the researcher directly observes the process of teaching and learning activities (KBM) English lessons. The researcher also obtaines the data in the form of learning tools used by the teacher as a guideline for carrying out teaching and learning activities (KBM) such as syllabus, lesson plans (RPP), Guidebook.

b. Interview

In this research, the purpose of the interview is used to support the data from observation, the researcher used a semi-structured interview to collect the data from participants. This interview type is included the "in-depth interview" category, which is its implementation is freer than a structured interview. In this case, the researcher asked the principal and the English teacher about the development of the English curriculum that had been done and what material had been applied. 
c. Documentation

In the research method, this document contains important notes obtained in the field or when the research is carried out either through writing or information from sources or based on documents obtained from the school.

\section{DISCUSSION}

\section{English Curriculum Development in SD NU Banat Banin Lamongan}

The researcher conducted the observation for four meetings in one month, the researcher made observations in Document Curriculum at SDNU Banat Banin Lamongan and English learning activity (KBM).

From the observation of the data on the document curriculum at SDNU Banat Banin Lamongan, the researcher found that curriculum development in English learning was done according to 2013 curriculum standards. The use of language for learning English uses English for textbooks, worksheets and introduction for English books the teacher prepares Work Sheets for each indicator in the 2013 curriculum for English lessons and was recorded in the form of a work book, here the preparation of English books was prepared together with the teachers who join C I C Malang. For Textbooks serve as reference learning together with other learning resources. Data from observations were analysed descriptively. After observations were made, the researcher used interviews to strengthen the data.

The interviews were conducted to know more about curriculum development in learning English which was done in SDNU Banat Banin Lamongan. The researcher interviewed School principal and English Teachers. From the interview, the researcher concluded that curriculum
The data analysis is used to explain the data or information that the researcher gets. The data used is qualitative. In analysing the data, the researcher analyses the data in observation and interview qualitatively.

development in English learning was done because of the addition of time in English lessons so that the material was increased and made its guidebook by the contents in the 2013 curriculum for English language lessons. And once a week there was an English Habit.

According to the observation and interview results. The researcher concluded the four aspects as curriculum development in learning English which was done in SDNU Banat Banin Lamongan starting from Development Goals, learning materials, learning methods, and learning evaluation.

1. Development Goals

According to observations and interviews, the purposed of developing English language learning done in SDNU Banat Banin Lamongan were according to the objectives of the 2013 curriculum to prepared Indonesian students to have the ability to live as individuals and citizens who are faithful, productive, creative, innovative, and effective as well able to contribute to the life of society, nation, state, and world civilization, Another goal is for students to have competency attitudes, knowledge, and skills so that they could be productive, creative, innovative, and effective personal and citizens. Another factor for curriculum development was that schools that have implemented a full-day school system, at the five-grade level, school activity starts at a seven to half-past four, with the presence of a full-day school system will have an impact on increasing learning time. 


\section{Learning Material}

The researcher found curriculum development such as the addition of subject matter, in this case, the school made its guidebook with the theme "English Workbook Fifth Grade", this book was made by the contents in the 2013 curriculum for English lessons. the researcher will explain the fifthgrade material which is applied in SDNU Banat Banin Lamongan in learning English.

The main material "Memorize vocabularies and Make many sentences" and the material as follows:

1) Student memorized vocabularies about kind of sport and writing sentences

2) Students could describe many pictures of sport using simple present tense!

3) Students could understand the text and look for the information from it!

4) Students Known tool of sport

5) Students could write the instruction of the sport

6) Students could look for the information from the text!

7) Students could difference word "some, any, much, many, a lot of

8) Students could write a short story by using picture

9) Students understand the used of the gerund

10) Students understand about countable noun

11) Students understand about uncountable noun

3. Learning Methods

According to observations done by the researcher at SDNU many use various learning methods. Because SDNU itself is a favourite school in Lamongan City, the facilities are also adequate such as $\mathrm{LCD}, \mathrm{AC}$, internet access, etc. It makes it easier for teachers to apply the learning method, in applying the learning method is adjusted to the material and grade level of each if in fifth-grade class the learning method that is often used is the discussion method, lecture method, and question and answer method. this is by the objective of the 2013 curriculum which emphasizes student activity.

To obtain in-depth data, the researcher also conducted interview with English teachers. The teacher explained if in fifth-grade class we often use discussion method, singing, drill, lecture method, and instructions on doing the task.

The researcher concluded the methods often used in fifth grade in SDNU there are the discussion method, the lecture method, drill, the question and answer method, and instructions on doing the task.

4 Learning Evaluation

According to observations done by the researcher the evaluation of learning done in SDNU Banat Banin Lamongan that is adjusted to the conditions of each class., if in fifthgrade class the student category is quite large, the teacher does a continuous evaluation. The evaluation of learning done by the teacher in the classroom. in the evaluation activity, the teacher notes the things that need to be done to improve the quality of teaching and learning and then the teacher says in the meeting all teachers.

The researcher concluded that the evaluation of learning done in SDNU were adjusted to the conditions of each class. Here, each teacher will record the things that need to be done and they would say in a meeting of all teachers.

Based on the results of data analysis from observation and interview, 
the researcher found that curriculum development in English learning was done according to 2013 curriculum standards. The use of language for learning English uses English for textbooks, worksheets and introduction. for English books the teacher prepares Work Sheets for each indicator in the 2013 curriculum for English lessons and was recorded in the form of a work book, here the preparation of English books was prepared together with the teachers who join C I C Malang. From the interview the researcher found four aspects that are done by SDNU Banat Banin Lamongan as curriculum development in learning English starting from the purpose of curriculum development, learning material, learning methods, and learning evaluation. This is known from the observation to the students and interviews that the researcher conducted with the principal and the teachers. Based on interviews, they explained the curriculum development in learning English was done by applying some additional material and adjusting the material for each class. They hold English habituation every Wednesday according to the material in each class.

\section{The Implementation of Teaching English Material in SD NU Banat Banin Lamongan}

The researcher conducted observations and also interviews with English teachers to know about the material applied at fifth gradeof SDNU Banat Banin Lamongan. From observations for four weeks and interviews with English teachers, the researcher concluded about the material applied in fifth grade, according of Sylabus, RPP, and the guidebook by the main material "Memorize vocabularies and Make many sentences" and the material as follows:
1) Student memorized vocabularies about kind of sport and writing sentences

2) Students could describe many pictures of sport using simple present tense!

3) Students could understand the text and look for the information from it!

4) Students Known tool of sport

5) Students could write the instruction of the sport

6) Students could look for the information from the text!

7) Students could difference word "some, any, much, many, a lot of

8) Students could write a short story by using picture

9) Students understand the used of the gerund

10) Students understand about countable noun

11) Students understand about uncountable noun

Based on the results of data analysis from observation and interview, the researcher found the material presented in fifth grade in SDNU Banat Banin Lamongan were grammar, translating text, making sentences, and knowing the difference in the meaning of a word. based on interviews to the teacher, the teacher explained we make our guidebooks from the content in the 2013 curriculum for English lessons, once every week on Wednesday there was a habit of English for first and second-grade class was memorize vocabularies, for the third-grade class were memorize vocabularies and make sentences, for the fourth, fifth and sixth class are make many sentences and translate.

\section{CONCLUSION}

Based on the data analysis, it can be concluded that:

1. The curriculum implemented was 2013 Curriculum

2. English Curriculum Development in SDNU Banat Banin Lamongan according to the interview there are four aspects has been done by covering starting from the purpose of curriculum 
development, learning material, learning methods, and learning evaluation.

3. The material presented in fifth grade in SDNU Banat Banin Lamongan is grammar, translating text, making sentences, and knowing the difference in the meaning of a word.

4. The material implemented is easier for students to understand

5. Made own guidebook in accordance to the contents of the 2013 Curriculum.

6. Hold habit of English every Wednesday according to the material in each class.

\section{REFERENCES}

Departemen Pendidikan dan Kebudayaan RI tentang Petunjuk Pembinaan pendidikan di sekolah. Jakarta 1994.

Undang - undang Republik Indonesia Nomor 20 Tahun 2003 tentang National Education System. Jakarta 2003.

Mas Nihayatul Amal Rawamerta. 2013. English Learning In Indonesia. Jawa Barat: SDN SUKAMERTA

Idi, Abdullah. 2011 Pengembangan Kurikulum; Teori dan Praktik. Yogyakarta: Arruz 2011.

Klein, Wolfgang. 1990 Second Language Acquisition, Melbourne: Cambridge University Press, 1990.

K. E. Suyanto, Kasihani, English for Young learners, Jakarta: Bumi Aksara, 2007.

Phillips, Sarah, Young Learners, UK: Oxford University Press, 2001. Prasetyo, Irawan, Logika dan Prosedur Penelitian, Jakarta: STIALAN Press, 1999.
T. Henson, Kenneth and Delmar Janke, Elementary Science Methods, United States of America: Mc Grow-Hill. Inc, 1984.

Brown, Douglas, Language Assessment Principles and Classroom Practices, San Fransisco State University: Pearson Education, Inc. 2004.

Komaria, O. The History of English Teaching in Indonesia, Unpublished Thesis, Jakarta: Universitas Katolik Indonesia Atmajaya, 1998.

Tilaar, H.A.R. 50 Tahun Pembangunan Pendidikan Nasional 1945-1995, Jakarta: Gramedia, 1995.

Ahid, N. Peran Guru dalam Implementasi Kurikulum 2013 untuk Mempersiapkan Generasi Emas. Paper presented in National Seminar: Bedah Kurikulum 2013; Repositioning Pendidikan Agama Islam (PAI) untuk Mewujudkan Generasi Emas. On Saturday, June 15, 2013. Kediri: Program Pascasarjana STAIN Kediri, 2013.

Sugiyono. Metode Penelitian Kuantitatif, Kualitatif dan R\&D. Bandung: PT Alfabet.2016.

Azwar, Saifuddin. Metode Penelitian. Pustaka Pelajar: Yogyakarta.2007.

Yendra Mengenal Ilmu Bahasa (Linguistik) (STKIP-PGRI) Sumatera Barat 2018.

Workbook English grade 5. English Teacher 2019. SDNU Banat Banin Lamongan 